Chicago-Kent College of Law

Scholarly Commons @ IIT Chicago-Kent College of Law

$11-1-2008$

\title{
The International Joint Commission and Great Lakes Diversions: Indirectly Extending the Reach of the Boundary Waters Treaty
}

\author{
A. Dan Tarlock \\ IIT Chicago-Kent College of Law, dtarlock@kentlaw.iit.edu
}

Follow this and additional works at: https://scholarship.kentlaw.iit.edu/fac_schol

Part of the International Law Commons, and the Water Law Commons

\section{Recommended Citation}

A. D. Tarlock, The International Joint Commission and Great Lakes Diversions: Indirectly Extending the Reach of the Boundary Waters Treaty, 54 Wayne L. Rev. 1661 (2008).

Available at: https://scholarship.kentlaw.iit.edu/fac_schol/774

This Article is brought to you for free and open access by the Faculty Scholarship at Scholarly Commons @ IIT Chicago-Kent College of Law. It has been accepted for inclusion in All Faculty Scholarship by an authorized administrator of Scholarly Commons @ IIT Chicago-Kent College of Law. For more information, please contact jwenger@kentlaw.iit.edu, ebarney@kentlaw.iit.edu. 
THE INTERNATIONAL JOINT COMMISSION AND GREAT LAKES DIVERSIONS: INDIRECTLY EXTENDING THE REACH OF THE BOUNDARY WATERS TREATY

\author{
A. DAN TARLOCK $\dagger$ \\ TABLE OF CONTENTS
}

I. INTRODUCTION: GREAT LAKES DIVERSION THREATS DIVERTED

FROM THE INTERNATIONAL JOINT COMMISSION .............................. 1671

II. BARRIERS TO THE NEGOTIATION OF THE COMPACT ........................ 1678

A. Thin Political and Scientific Justification................................. 1679

B. A Violation of the Judicial Common Market? ......................... 1681

C. International Trade Law ......................................................... 1683

III. ENTER THE INTERNATIONAL JOINT COMMISSION......................... 1683

A. A Rationale for Leaving Twenty Percent of the World's Fresh

Water in Place ...................................................................... 1685

B. International Trade Law ......................................................1690

IV. CONCLUSION: A MOMENT IN TIME................................................. 1693

\title{
I. INTRODUCTION: GREAT LAKES DIVERSION THREATS DIVERTED FROM THE INTERNATIONAL JOINT COMMISSION
}

The 1909 Boundary Waters Treaty (Treaty) ${ }^{1}$ is a model of international water resources cooperation because it provides a permanent dispute mechanism, the six member International Joint Commission (IJC). ${ }^{2}$ Thus, both Canada and the United States have much

$\dagger$ Distinguished Professor of Law, Chicago-Kent College of Law. A.B., 1962, Stanford University; LL.B., 1965, Stanford University. Honorary Professor of Law, University of Dundee UNESCO Centre for Water Law, Science, and Policy. The author discloses that he was a consultant to the International Joint Commission (IJC) in 19992000 during the preparation of Protection of the Waters of the Great Lakes, discussed in this Article. The views expressed in this Article are solely the author's and do not reflect the views of the Canadian or United States Commissioners and staff past and present. I would like to thank Professor Noah Hall, Wayne State University School of Law, and United States IJC Commissioner Sam Speck, for their helpful comments and insights.

1. Treaty Between the United States and Great Britain Relating to Boundary Waters Between the United States and Canada, U.S.-U.K., Jan. 11, 1909, 36 STAT. 2448 [hereinafter Treaty].

2. See David Lemarquand, The International Joint Commission and Changing Canada-United States Boundary Relations, 33 NAT. RES. J. 59, 62-67 (1993) (providing a brief history of the background of the Treaty). For a more detailed histories, see L.M. BLOOMFIELD \& GERALD F. FITZGERALD, BOUNDARY WATERs PROBLEMS OF CANADA AND 
to celebrate on the 100th anniversary of the Treaty. However, the most interesting aspect of the Treaty is the regime's ability to evolve through state practice beyond its original dispute resolution function, despite the inconsistent support for IJC involvement in transboundary water issues of the United States. The Treaty has been severely criticized by governments and non-governmental organizations (NGOs), especially in Canada, for its limitations. ${ }^{3}$ Taking the Great Lakes alone, the area is too large and the resource management issues too complex to permit a single governance regime. ${ }^{4}$ Nonetheless, the IJC has been able to use the reference process to adapt "the spirit of the Treaty" to the new resource challenges, primarily environmental, that the Great Lakes face. ${ }^{5}$ This Article offers an example of the power of the IJC to overcome the Treaty's limitations by using its status as an international body to constructively influence the development of a new and important Great Lakes management regime outside of the Treaty framework.

Between 2001 and 2005, the eight Great Lakes states negotiated an innovative interstate compact, The Great Lakes-St. Lawrence River Basin Compact (Compact). ${ }^{6}$ By 2008 , all eight basin states had adopted the necessary legislation and secured the constitutionally necessary joint congressional consent. ${ }^{7}$ In brief, the Compact makes it very difficult to

the United States (1958); A.D.P. Heeney, Along the Common Frontier: The INTERNATIONAL JOINT COMMISSION (1967); William R. Wilbughby, Expectations and Experience 1909-1979, in R. SPENCER, J. KIRTON \& K.R. NOSSAL, THE INTERNATIONAL JOINT COMMISSION SEVENTY YEARS ON (1981).

3. See, e.g., David Allee, Subnational Governance and the International Joint Commission: Local Management of United States and Canadian Boundary Waters, 33 NAT. RES. J. 133 (1993) (arguing that the IJC is only used to help legitimize a political solution to a conflict.). See also Robert V. Wright, The Boundary Waters Treaty: A Proposed Public Submission Process to Increase Public Participation, Accountability, and Access to Justice, 54 WAYNE L. REV. 1609 (2008); Lee Botts \& Paul Muldoon, Using the Boundary Waters Treaty for the 21st Century: Revitalizing the Great Lakes Governance Regime, 54 WAYNE L. REV. 1553 (2008).

4. See generally id.

5. See generally id.

6. See Great Lakes-St. Lawrence River Basin Water Resources Compact, available at http://www.cglg.org/projects/water/docs/12-13-05/Great_Lakes-St_Lawrence_River_Basin_Water_Resources_Compact.pdf (last visited Apr. 6, 2009); see also Noah D. Hall, Toward A New Horizontal Federalism: Interstate Water Management in the Great Lakes Region, 77 U. Colo. L. REV. 405 (2006) (analyzing the innovative aspects of the Compact).

7. Great Lakes-St. Lawrence River Basin Compact, Pub. L. No. 110-342, 122 Stat. 3739 (2008) [hereinafter Compact]. The Compact was proceeded by a soft law interstate agreement, the Great Lakes Charter. See Peter V. McAvoy, The Great Lakes Charter: Toward a Basinwide Strategy for Managing the Great Lakes, 18 CASE W. RES. J. INT'L. L. 49, 50 (1986) (summarizing "the development of the Charter and attempts to 
divert water outside the Great Lakes Basin. ${ }^{8}$ Even small communities that straddle the divide between the Great Lakes and other drainages, which often includes a small part of a state, must meet a high standard to gain access to water located only a few miles away. ${ }^{9}$ Similar antidiversion prohibitions exist in Canada. In 2002, for example, Canada enacted a strong federal anti-diversion law. ${ }^{10}$

The Compact is a reaction to several proposed or possible projects to divert the Lakes' water to the more arid regions of the United States or undisclosed water-short countries. ${ }^{11}$ In reality, the threatened plans or bulk transfers were either economically or politically infeasible or involved trivial amounts of water. ${ }^{12}$ Nonetheless, they touched raw political nerves in both countries. In the United States, Congress has the plenary power to allocate the Lakes, and the eight basin states worried that they would progressively lose political power as the country's population continued to tilt to the sun. ${ }^{13}$ The possibility of Congressionally mandated transfers to bail out Phoenix or other areas helped spur approval of the Compact. ${ }^{14}$

In Canada, nationalist Greens raised the specter of the loss of Canadian sovereignty over its abundant water resources, but even more dispassionate and knowledgeable experts argued that Canada had no surplus waters to bail out the United States' profligate use of its waters. ${ }^{15}$

characterize the role that the Charter is playing and will play in stimulating and guiding the evolution of a regional water management framework").

8. Compact, supra note $7, \S 4.8$.

9. See generally Compact, supra note 7.

10. International Boundary Waters Treaty Act, R.S., Ch. I-20 (2002).

11. In the late 1970 s, the U.S. Army Corps of Engineers released a Congressionally mandated study on ways to recharge the depleted Ogallala Aquifer from adjacent areas. See, e.g., Peter AnNin, The Great Lakes Water Wars, 68 (2006). The study did not include any proposal to construct a pipeline from Lake Superior to the High Plains, but it triggered regional fears that the water-short West would eventually ask Congress to bail it out with Great Lakes water. See generally id. The fears were reinforced by the 1982 Supreme Court decision, Sporhase v. Nebraska, 458 U.S. 941 (1982), discussed, infra footnotes 62-71, which held that groundwater still in the ground was an article of commerce and thus subject to the Dormant Commerce Clause; see also ANNIN, supra, at 57-81. (discussing reactions to feared diversions and Sporhase); Great Lakes Legal Seminar: Diversion and Consumptive Use, 18 CASE W. RES. J. INT'L. L. 1 (1986) (providing a good snapshot of the diversion fears and range of legal responses in the mid1980s).

12. ANNIN, supra note 11, at 194 (discussing one empty bulk freighter).

13. See, e.g., Communities Take Action to Protect Great Lakes, National Public Radio, available at http://www.npr.org/templates/story/story.php?storyId=90517072\&$\mathrm{ft}=1 \& \mathrm{f}=1007$ (last visited Apr. 6, 2009).

14. Id.

15. Two respected Canadian academics criticized the Annex 2001 process, which led to the Compact, as an abdication of the Canadian federal government's responsibility 
This argument drew on the long frustration caused by the population and economic imbalance between the two countries and the long history of perceived subordination of Canadian interests to its major trading partner. ${ }^{16}$

This Article does not address the merits of the Compact. Its focus is on the paradox that an international water management regime, which deals with the core of the Treaty and the use of the Great Lakes, was negotiated outside the regime. One might expect that the IJC would lead an investigation of the issue and recommend either amendments to the Treaty or parallel federal legislation in Canada and the United States. In fact, the Compact superimposed yet another new regulatory regime over the Treaty regime. ${ }^{17}$ The only attempt to harmonize the two regimes is found in section 8.2 , which was added toward the end of the process. ${ }^{18}$ section 8.2 makes the Treaty regime superior and provides in part that

[n]othing in this Compact is intended to infringe nor shall any term hereof be construed to infringe upon the treaty power of the United States of America, nor shall be construed to alter or amend any treaty or term thereof that has been or may hereafter be executed by the United States of America .... Nothing in this Compact is intended to affect nor shall be construed to affect the application of the Boundary Waters Treaty of 1909 whose requirements continue to apply in addition to the requirements of this Compact. ${ }^{19}$

There are good reasons for the bypass. First, there was no boundary waters dispute for the IJC to adjudicate. The diversion threats were just that, and remote as well. Ironically, at Canada's insistence, the IJC was given limited adjudicatory powers. ${ }^{20}$ The Treaty only applies to diversions or obstructions that affect the natural level of the lakes. ${ }^{21}$ In addition, the use of IJC to adjudicate environmental controversies has not

because it "would leave the provinces with no control over diversions in the U.S. [and] [i]t would also give the U.S. significant say over water-related developments in Canada." D. W. Schlinder \& Adele M. Hurley, Notes for Remarks to the Centre for Global Studies Conference on Canada/U.S. Relations University of Victoria (Nov. 2004), in Rising Tensions: Canada/U.S. Cross-Border Water Issues in the 21st Century, at 11, available at http://www.powi.ca/pdfs/watersecurity/uvic_finalnotes_remarks.pdf (last visited June 9, 2009).

16. Id.

17. See generally Compact, supra note 7.

18. Compact, supra note $7, \S 8.2$.

19. Id.

20. HEENEY, supra note 2.

21. Treaty, supra note 1, art. 3. 
been met with success. ${ }^{22}$ The IJC asserted the power to determine its jurisdiction absent a request to adjudicate or a reference from the two countries. ${ }^{23}$ This heresy was quickly rejected and adjudication is no longer requested by the two governments. ${ }^{24}$ Second, Articles II and III of the Treaty impose a high burden of proof on any assertion of IJC jurisdiction. ${ }^{25}$ The victim country must prove either injury or a lowered lake level. ${ }^{26}$ Third, the status of Lake Michigan, which forms no part of the Canada-United States boundary, ${ }^{27}$ as a boundary water, remains unsettled. ${ }^{28}$ Fourth, the longer a treaty stands, the harder it is to amend it.

22. The Trail Smelter dispute was originally referred to the IJC, but the United States rejected the recommended award and the dispute was eventually resolved by a special arbitral tribunal. See Michael J. Robinson-Dore, The Trial Smelter, Is What's Past Prologue? EPA Blazes a New Trial for CERCLA, 14 N.Y.U. ENVTL. L. J. 233, 249-51 (2006). In discussing a United States CERCLA action against the present owners of the smelter, Professor Robinson-Dorn noted that " $[t]$ he Boundary Waters Treaty contains no provision preempting the application of domestic law." Id. at 305. Pakootas v. Teck Cominico Metals, Ltd., 452 F.3d 1066, 1077 (9th Cir. 2006), holds that the presumption against the extraterritorial application of statutes does not apply to hazardous substance releases which come to rest and cause harm in the United States. See John H. Knox, The Boundary Waters Treaty: Still Ahead of Its Time, 54 WAYNE L. REV. 1591 (2008). However, NGOs continue to argue that the IJC has jurisdiction outside of the reference procedure. A 2006 submission to the Commission of Environmental Cooperation (CEC), created by the NAFTA Environmental Side Agreement, illustrates the power of one nation to block IJC action. See Determination in Accordance with Article 14(1) of the North American Agreement for Environmental Cooperation, SEM 06-002/04/14(1), June 8,2006 , at 1 [hereinafter Determination]. For decades Canada has been concerned with the release of polluted water in Devil's Lake, North Dakota into Canada. Id. at 2. Manitoba asked the Canadian federal government to refer the issue to the IJC, but the Bush Administration refused to do so. See, e.g., Oxford Analytica, U.S.-Canada Water Disputes Appear Likely to Keep Flowing, available at http://thehill.com/op-eds/u.s.canada-water-disputes-appear-likely-to-keep-flowing-2007-10-17.html (last visited Feb. $8,2009)$. After this decision, a group of United States NGOs filed a CEC submission which asserted that Canada and the United States have failed to enforce the Boundary Waters Treaty by refusing to refer the alleged cross-border pollution from Devil's Lake, North Dakota to the IJC. Determination, supra, at 1 . The submission was dismissed because of the considerable legal uncertainty as to whether the Treaty was a law or regulation in either Canada or the United States as Article 14 of the Side Agreement requires. Id. at 3. For an NGO perspective on the submission, see Wright, supra note 3.

23. Lemarquand, supra note 2 at 75-76.

24. Noah D. Hall, Bilateral Breakdown: U.S.-Canada Pollution Disputes, 21 NAT. RES. \& ENV. 18, 19 (2006).

25. Treaty, supra note 1, arts. 2-3.

26. Joseph W. Dellapenna, International Law's Lessons for the Law of the Lakes, 40 U. MiCH. J. L. REFORM, 747, 754-57 (2007).

27. Map of Lake Michigan, available at http://encarta.msn.com/map_701513942/michigan_lake.html (last visited Apr. 6, 2009).

28. Richard B. Bilder, Controlling Great Lakes Pollution: A Study in United StatesCanadian Cooperation, 70 MiCH. L. REV. 469 (1970). 
In short, the Treaty is not structured to deal with political rather than actual diversion problems.

The basin states thus decided to address the problem themselves in close cooperation with the provinces of Ontario and Quebec. They produced a domestic agreement which has two significant international law aspects and one domestic law aspect. ${ }^{29}$ First, it was the exclusive product of joint negotiations among the eight basin states and the provinces of Ontario and Quebec. ${ }^{30}$ Orthodox constitutional law teaches that the federal government not the states can conduct foreign policy. ${ }^{31}$

In practice, Canadian provinces and American states have a long history of sub-treaty agreements. ${ }^{32}$ The Compact is a particularly interesting example of sub-constitutional foreign affairs initiatives by states and their foreign federal counterparts that occurred due to informal national government sanction. The Compact comes close to a bi-national treaty because Ontario and Quebec adopted parallel legislation. ${ }^{33}$ From the Canadian perspective, the arrangement avoids the constitutional issues that would arise, if the federal government were to try and force the provinces to comply with the environmental obligations of the treaty. ${ }^{34}$ It also avoided recognizing any formal attempt on the part of

29. Compact, supra note 7.

30. Id.

31. U.S. CONST. art. $1, \S 10$. ("No State shall enter into any Treaty, Alliance, or Confederation ....").

32. See generally Michael Byers, The Role of Law In International Politics (2000).

33. See generally Dellapenna, supra note 26.

34. Peter W. Hogg, Constitutional Law of Canada 254-56 (2nd ed. 1985). The relationship between the federal government and Canadian provinces is complicated because Canada has long been a part of the British Empire. Id. Canada did not have the power to enter into treaties until Great Britain delegated this power in the 1919 Treaty of Versailles, which ended World War I. Id. The delegation of authority was confirmed in the Statute of Westminster of 1931 and again in 1947. Letters Patent to the Office of Governor General of Canada, R.S.C. 1970, app. II No. 35. However, treaties are not part of domestic law and thus binding on Canadian provinces in contrast to United States law. U.S. CONST. art. VI. The diplomatic practice in Canada is to involve the provinces directly in treaty negotiations because provincial implementation of legislation is often necessary. HOGG, supra at 254-56. Provinces, led by Quebec, have gone beyond this practice and have asserted the right to make treaties. Id. This power cannot be found in past Canadian constitutional law when it was part of the North American British Empire or in post-1982 law after Westminster relinquished any vestiges of authority over Canada. Id. The federal government strongly asserts the "ultimate prerogative to enter into" international agreements. George Anderson, Canadian Federalism and Foreign Policy, 27 CAN.-U.S. L. J. 45, 51 (2001). The Boundary Waters Treaty avoids this problem because it in an Empire Treaty, which is binding on the provinces under the Constitution Act of 1867. Constitution Act, 1867, 30 \& 31 Vict. ch. 3 (U.K), as reprinted in R.S.C., No. 5 (app. 1985, 132) [hereinafter Constitution Act]. The balance of 
Quebec to act as a sovereign nation. ${ }^{35}$ From the United States' perspective, it preserved the myth that the federal government defers to state water allocation law. ${ }^{36}$

The second interesting aspect is that the Compact adopts, with little fanfare, directly and indirectly several contested key principles of international environmental law such as precaution and the recognition that the Lakes are a common heritage of humankind. ${ }^{37}$ Third, given the crucial national and international significance of the Great Lakes, it is striking that the United States federal government played almost no role in the Compact, ${ }^{38}$ it did not even send a federal representative to the Compact processes as it has done when an interstate compact is being negotiated to allocate a river in order to pave the way for federally subsidized dams. ${ }^{39}$

The IJC played an important role in the Compact process in two crucial ways. First, it addressed some of the difficult legal questions that

provincial versus federal foreign affairs capacity nonetheless remains open in Canada because in addition to the long transition from being part of the British Empire to becoming an independent nation, the country has a strong federal system in which the provinces have considerable exclusive authority especially with respect to natural resources. See Email from Noah Hall, infra note 87. Provinces might refuse to comply with a non-Empire international treaty signed by the federal government if the treaty deals with water allocation, including the allocation for environmental values as the Compact does. $I d$. The three maritime provinces and the province of Canada (now divided into Ontario and Quebec) formed modern Canada in 1867. HoGG, supra at 25456. The Constitution Act of 1867 gives the provinces exclusive authority to public land management and property, which is understood to include water. Constitution Act, supra, at section 92. Section 91 reserves to the federal government the residual power to legislate for "Peace, Order, and good Government of Canada," but the scope of this power as it relates to water has not been tested. Id. at section 91; see also P.H. PEARSE, F. Bertrand \& J. W. Maclaren, CuRrents of Change: Final Report Inquiry on FEDERAL WATER POLICY 61-84 (1985) (discussing the precarious balance between federal and provincial authority over water allocation and management).

35. HoGG, supra note 34 , at $254-56$.

36. The "myth" has its roots in California Oregon Power Co. v. Beaver Portland Cement $\mathrm{Co}$., which held that three nineteenth century public lands statutes severed water from the public domain and gave the states exclusive authority to choose a legal system to allocate western waters. 295 U.S. 142, 154-55 (1935). The federal government has always exercised power over waters through the commerce, property and treaty powers, and environmental statutes such as the Clean Water Act and Endangered Species Act which can preempt state law. See Reed D. Benson, Deflating the Deference Myth: National Interests vs. State Authority Under Federal Laws Affecting Water Use, 2006 UTAH L. REV. 241 (2006).

37. I have addressed this aspect of the Compact in A. Dan Tarlock, The Great Lakes as an Environmental Heritage of Humankind: An International Law Perspective, $40 \mathrm{U}$. MICH. J. L. REFORM 995 (2007).

38. See generally id.

39. Id. 
were hindering the negotiations. Second, the IJC helped make a sciencebased case for the anti-diversion regime in face of arguments that "locking up" the Lakes was economically irrational, unnecessary and that a conventional division of the waters among the states would be a superior response. ${ }^{40}$ This Article advances the modest thesis that the IJC's role is a case study in how international treaty organizations can overcome the limitations that are inherent in a body controlled by a limited number of sovereigns. International bodies which are willing to take the risk of taking a strong stand on an issue can help international environmental norms to evolve through their incorporation into domestic legal regimes and can adapt these regimes to changed circumstances not contemplated in the treaty.

\section{BARRIERS TO THE NEGOTIATION OF THE COMPACT}

To understand the niche that the IJC found to influence the Compact process, it is necessary to understand the barriers that threatened to block any agreement. The Compact faced two sets of barriers. The first were the conventional disincentives that often prevent interstate cooperation in sharing a contested water resource. The second were a set of legal and scientific issues that were unique to the Great Lakes. On the plus side, most of the present uses of the lake are non-consumptive. It is easier to agree on the balance among non-consumptive as opposed to consumptive uses. $^{41}$

Since the 1920s, interstate compacts have been hailed as the best way to share interstate resources, but water compacts are hard to negotiate. ${ }^{42}$ The riparian states must either be convinced that an allocation regime is superior to the status quo or that at least some of them cannot maintain the status quo in face of proposed uses by other states. ${ }^{43}$ For example, in 1922, the seven Colorado River basin states allocated the Colorado River between the Upper and Lower basins to

40. See A. Dan Tarlock, The Strange Career of the Dormant Commerce Clause and International Trade Law in the Great Lakes Anti-Diversion Regime, 2006 MicH. ST. L. REV. 1375, 1379 (2006).

41. B. Timonthy Heinmiller, The Boundary Waters Treaty and Canada-U.S. Relations in Abundance and Scarcity, 54 WAYNE L. REv. 1499, 1524 (2008).

42. See, e.g., Josh Clemons, Interstate Water Disputes: A Road Map for States, available at http://www.olemiss.edw/orgs/SGLC/MS-AL/acf.htm (last visited Apr. 6, 2009). Jerome C. Muys, George William Sherk \& Marilyn O'Leary, Utton Transboundary Center Model Interstate Compact, 77 NAT. RES. J. 17, 25 (2007). But see Charles J. Meyers, The Colorado River, 19 STAN. L. REV. 1, $45-48$ (1966) (stating that Congressional apportionment is superior to a compact).

43. Robert H. Abrams, The Boundary Waters Treaty of 1909 as a Model for Interjurisdictional Water Governance, 54 WAYNE L. REV. 1635, 1645 (2008). 
prevent fast-growing southern California from claiming the whole flow of the river under the doctrine of prior appropriation. ${ }^{44}$ Often states balk because a compact will make them worse off because they must decrease their water use. For example, this fear has blocked the negotiation of an allocation of the Apalachicola-Chattahoochee-Tallapoosa watershed among Alabama, Florida, and Georgia. ${ }^{45}$ Georgia argued that its upstream position had the most to lose from any agreement that requires minimum flows downstream for navigation enhancement and aquatic ecosystem protection. ${ }^{46}$

The situation in the Great Lakes was different. Because serious diversions are hypothetical, the problem of dividing a limited resource among competing interests did not exist. ${ }^{47}$ Since the value of the Compact was primarily symbolic, ${ }^{48}$ each state stood to gain politically by blocking future moves by "others" outside the region. Instead of the usual problems, the Great Lakes states faced three somewhat unique barriers, one political and scientific and the other two legal.

\section{A. Thin Political and Scientific Justification}

The first problem was that the Compact appeared geopolitically, constitutionally and hydrologically unfair, inefficient, irrational, and unnecessary. Quite simply, the goal of the basin states and provinces was to lock up twenty percent of the world's fresh water supplies almost exclusively for non-consumptive uses. ${ }^{49}$ The numbers get worse because the Great Lakes account for ninety-five percent of the United States'

44. See Colorado River Compact of 1922, available at http://www.usbr.gov/lc/region/pao/pdfiles/crcompct.pdf (last visited Apr. 6, 2009).

45. See, e.g., Dave Feldman, Water Policy for Sustainable Development, 140 (2007).

46. Id.

47. See Ken Conca, Governing Water: Contentious Transnational Politics AND GLOBAL INSTITUTION BUILDING 73-80 (2006) (discussing the stresses that many river basins face and the barriers they pose to cooperative management among riparian states).

48. The Compact does impose two real costs on the basin states. First, the straddling communities' standard may block many small transfers across the basin line. Second, the Compact will create pressure for the additional regulation of surface and groundwater. States such as Indiana, Illinois, Ohio, New York, and Pennsylvania have resisted the strong regulated riparianism adopted in Minnesota, Michigan, and Wisconsin. The Compact was briefly held up when an Ohio state representative argued that it would erode Ohio's power to control its water resources. Michael Scott, Great Lakes Water Compact Weighs on Region's Future, THE Plain DeAler (Apr. 6, 2008), available at

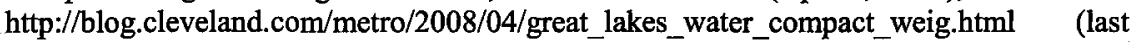
visited Apr. 6, 2009).

49. See Compact, supra note $7, \S 4 a$. 
surface supplies ${ }^{50}$ but only ten percent of the population lives in the basin. ${ }^{51}$ Given the shift of population to the more arid areas of the country ${ }^{52}$ one can legitimately ask: what is the rationale for this action, especially since all the diversion threats were and are, speculative at best and highly unlikely to come to fruition for environmental and economic reasons? $?^{53}$

During the negotiations two rationales to overcome these problems emerged, but they lacked a coherent scientific basis. First, the eight basin states argued that their political power would continue to decrease as the region fell behind most of the country in population growth. ${ }^{54}$ Thus, it was a case of striking while the iron was hot, especially because there was no serious opposition in Congress or the rest of the country to the Compact. $^{55}$

The second rationale came from Canada. Many Canadians were (and remain) deeply convinced that eventually "their" water would flow south and west. ${ }^{56}$ In 2007, Dr. Frank Quinn, a leading Canadian expert on water policy, surveyed the shift in the United States to water conservation and demand management and the gap between the perceptions of the Canadian public and the historic tendency of the Canadian federal government not to rule all diversions off the table in the name of good relations with the "elephant" to the south. ${ }^{57}$ Admitting that there was no present or immediately foreseeable diversion proposal on the table, he nonetheless concluded that "[s]hould the US find itself in desperate need for water in the future ... what would prevent the US

50. See Great Lakes Facts and Figures, available at http://www.greatlakes.net/lakes/ref/lakefact.html (last visited Apr. 6, 2009).

51. See Dale R. Olen, Great Lakes Compact Needs Wisconsin's Approval Now, available at $\mathrm{http}: / / \mathrm{www} . j s o n l i n e . c o m / n e w s / o p i n i o n / 29477969 . \mathrm{html}$ (last visited Apr. 6, 2009).

52. See, e.g., U.S. 2000 Census Finds Record Growth, available at http://archives.cnn.com/2001/US/04/02/us.census/index.html (last visited Apr. 6, 2009).

53. During the 1980s, I once raised this issue with Donna Wise, the President of the Center for the Great Lakes and was informed that I was right but ultimately wrong because politicians in the region thought that diversions were a problem and, thus, they were a problem.

54. See, e.g., Tim Jones, Fate of Great Lakes' Water Looking Fluid, L.A. TimEs, Oct. 28,2007 at A-30.

55. Statements of Sam Speck (on file with author).

56. See. e.g., Tim Morris, Great Lakes Agreement Could Spring Leak, THE STAR (Apr. 10, 2007), available at $\mathrm{http}: / / \mathrm{www}$.thestar.com/article/201141 (last visited Apr. 6, 2009).

57. See Frank Quinn, Water Diversion, Export and Canada-US Relations: A Brief History, Program on Water Issues, Munk Centre for International Studies, available at http://www.powi.ca/pdfs/events/powi20070910_12pm_Water_Diversion.pdf (last visited Apr. 6, 2009). 
from simply taking a disproportionate share of waters along the international boundary, specifically . . . the Great Lakes?"58 This said, while assuaging Canadian angst may be laudable, it is not a complete rationale for putting the lakes off limits to the rest of the United States.

\section{B. A Violation of the Judicial Common Market?}

The lock-up strategy was not only scientifically and economically suspect, but it was a presumptive violation of the Dormant Commerce Clause of the United States Constitution. ${ }^{59}$ The Compact solves this issue; a compact becomes federal law with Congressional approval and is an exercise of Congress' power to waive the Dormant Commerce Clause. ${ }^{60}$ However, the issue was very alive during the 1980 s and 1990 s. State resource export bans have long been struck down on the theory that no state can hoard its resources to the detriment of other states. ${ }^{61}$ A 1982 United States Supreme Court decision, Sporhase v. Nebraska ${ }^{62}$ caused great concern on both sides of the border and cast a chill on the soft law regime that preceded the Compact and on its negotiation.

Sporhase was a farmer whose farm straddled the Colorado-Nebraska border. ${ }^{63}$ When Colorado's strict groundwater conservation regime blocked access to groundwater on the Colorado portion of his land, he proposed to pump the water from the Nebraska portion and use it in Colorado. ${ }^{64}$ In contrast to Colorado, Nebraska at the time followed a modified version of the common law on groundwater use, which gave overlying landowners the right to pump water with few restrictions. ${ }^{65}$ State law even allowed exports, but only if the host state had reciprocal

58. Id. at 5. In January 2008, the distinguished United States environmental advocate and activist, Robert F. Kennedy, Jr., warned Canada that it must resist pressure to sell its water to the United States to avoid "an environmental catastrophe" in Canada. Nick Lees, Canada Urged Not to Share Water with Americans, THE EDMONTON JouRNAL (Jan. 18, 2008), available at http://www.commondreams.org/archive/2008/01/18/6460 (last visited Apr. 6, 2009).

59. See Tarlock, supra note 40 , at 1379 ; U.S. ConST. art. I, $\$ 8$.

60. New England Power Co. v. New Hampshire, 455 U.S. 331 (1982). Congress did this twice in 1986: 42 U.S.C. $\$ 1926 \mathrm{~d}-20$ (2009) and Water Resources Development Act of 2000, Pub. L. No. 106-541, §504, 114 Stat. 2572 (2000).

61. See, e.g., Pennsylvania v. West Virginia, 262 U.S. 553, 596-98 (1923) (holding that although natural gas supplies in West Virginia were waning, the state was not entitled to favor its interests over those of other states, as the natural gas constituted a "lawful article of commerce").

62. 458 U.S. 941.

63. Id. at 944 .

64. Id.

65. Id. 
rights to withdraw water for use in Nebraska ${ }^{66}$ which Colorado law did not have. ${ }^{67}$ The Supreme Court held that the farmer was entitled to his water because "water is an article of commerce" subject to the Dormant Commerce Clause. ${ }^{68}$

Nebraska defended its statute on the state's long recognized power, to control the allocation of resources within its borders; captured in the phrase "state ownership," to control the allocation. ${ }^{69}$ Though the state ownership defense was accepted by Justice Holmes in $1908,{ }^{70}$ the Court rejected that argument and labeled state ownership as a fiction that has always been subject to the Commerce Clause. ${ }^{71}$ Sporhase was read for the principle that all export bans are presumptively unconstitutional, a reading reinforced by the Court's aggressive use of the Dormant Commerce Clause to invalidate protectionist environmental legislation. ${ }^{72}$

The case left a host of questions unanswered. For example, should a regional-international agreement be treated differently from a unilateral export ban? ${ }^{73}$ The reach of Sporhase was important because between 1985 and the beginning of Annex 2001, the Compact negotiation period, the states tried to control diversions under the soft, non-binding Great Lakes Charter, which was reinforced by Congressional legislation which allowed state export bans. ${ }^{74}$

66. Id.

67. Id. at 957.

68. Sporhase, 458 U.S. at 960.

69. Id. at 951 .

70. Hudson County Water Co. v. McCarter, 209 U.S. 349 (1908).

71. Sporhase, 458 U.S. at 951.

72. See, e.g., Chemical Waste Mgmt., Inc. v. Hunt, 504 U.S. 334, 339-40 (1992) ("No State may attempt to isolate itself from a problem common to the several States by raising barriers to the free flow of interstate trade."); Or. Waste Systems, Inc. v. Or. Dept. Envtl. Quality, 511 U.S. 93 (1994) (declaring unconstitutional Oregon's excessive surcharge on hazardous waste imported from other states). This line of cases has been widely criticized as an unwarranted interference with the power of the states to regulate. Liza Heinzerling, The Commercial Constitution, 1995 SuP. CT. REV. 217 (1995). Justices Scalia and Thomas believed that the doctrine had no basis in the Constitution and was an unjustified intrusion on state regulatory power. See id. at 233. Nonetheless, the Court has created only limited exceptions for environmental regulation. Maine v. Taylor, 477 U.S. 131 (1986) (holding a ban on non-native "baitfish" is constitutional because the state demonstrated that the ban was necessary in light of uncertainty as to the effects of the possible presence of parasites and nonnative species having on the state's fisheries). However, the case opens up the possibility of a broader ecosystem protection defense.

73. I have addressed these and related issues in Tarlock, supra note 40.

74. If Sporhase were not enough, a prominent western water lawyer hired by the Great Lakes Governors caused a stir when he concluded that the Water Resource Development Act of 1986 (WRDA) was an unconstitutional delegation of power because it had no standard. ANNIN, supra note 11, at 198-202. 


\section{International Trade Law}

In addition to the Dormant Commerce Clause, a second common market problem arose. "Canadian Nationalist Greens, among others, raised the argument that a Canadian export ban [which was ultimately adopted by the federal parliament], was illegal under the General Agreement on Tariffs and Trade (GATT) because it discriminated against non-Canadians desiring to export water." 75 A similar argument was made under NAFTA ${ }^{76}$ These arguments were stoked by the Lockheed Report, which recommended that the best way to avoid all the constitutional problems with the Charter-WRDA regime was to enter into an interstate compact that gave each state a share of the lakes to use as it saw fit. ${ }^{77}$ The recommendation was the opposite of what the Lakes and most NGOs were seeking. Canadians seized on the recommendation as an attempt to perpetrate the ultimate water evil: "commodify" the resource. $^{78}$ However, commodification fears can be found in the United States. For example, in 2005 the Governor of Michigan ordered state officials to block a proposal by Nestle to withdraw spring water for bottled water sales unless Nestle could prove that the bottles would be sold exclusively within the basin. ${ }^{79}$

\section{ENTER THE INTERNATIONAL JOINT COMMISSION}

The IJC was able to influence Compact negotiations by leveraging the reference process. The Treaty allows the IJC to investigate issues referred to it by the two governments. ${ }^{80}$ Once the two nations agree to

75. Tarlock, supra note 40 , at 1378.

76. North American Free Trade Agreement, Can.-Mex.-U.S. Dec. 8-17, 1992, 32 I.L.M. 289 (1993); see also Tarlock, supra note 40, at 1393.

77. ANNIN, supra note 11, at 199.

78. See Maude Barlow, Blue Gold: The Fight to Stop the Corporate Theft of THE WORLD'S WATER (New Press, 2002).

79. See Peter LuKe, Great Lakes States Circle the Wagons on Fresh Water (2006). This incredible anti-commodity argument was made in litigation challenging Perrier's planned diversion of spring waters in Michigan. Mich. Citizens for Water Conservation v. Nestle Waters N. Am., Inc., Case No. 01-14563-CE (Mich. 9th Judicial Cir. 2003), aff'd on other grounds, 709 N.W.2d 174 (Mich. App. 2005), rev'd on standing grounds, 269 Mich. App. 25, 479 N.W.2d 280 (2007). Earlier opponents of the proposed extraction argued that when groundwater was used to produce commodities, the commodities could only be consumed on the overlying land. Id. The trial court rejected the argument because the reasonable use adopted by Michigan only requires that the water be applied on overlying land. Id.

80. Treaty, supra note $1, \S 4$. In theory, either country could submit a reference but the IJC's consistent practice has been to act only when both countries agree to refer an issue to it. See generally id. 
refer a matter to the Commission, it can investigate the issue, holding public hearings on the basin and issue a report. ${ }^{81}$ State practice has made the reference process the Commission's most important function and the major source of its political influence. This level of influence is due to the custom of joint Canada-United States requests, which create "at least an implied obligation on both of them to deal with the report in a responsive way." "82 Reference reports have often laid the foundation for Canada-United States cooperation on major issues or at least provided a broad, relatively neutral analysis of issues superior to studies subject to the immediate pressures of national politics. ${ }^{83}$

In 1999, the two governments agreed to an IJC reference. The resulting 2000 report, Protection of the Waters of the Great Lakes: Final Report to the Governments of Canada and the United States (Report), ${ }^{84}$ helped overcome the three barriers to the Compact, especially the first and third. The reference came at the right moment in time. The Report was the last example of the positive role that the Commission played during the Clinton administration in helping to shape the policy debate about the future of the Great Lakes' in regards to environmental issues. Both the Canadian and United States Commissioners had a strong commitment to the conservation of the lakes ${ }^{85}$ and both the Canadian and United States sections were led by accomplished water professionals at home in both the technical and policy world. ${ }^{86}$ In addition, there was an overlap between the key state players and the $\mathrm{IJC}^{87}$

81. Id.

82. The Right Honorable Herb Gray, Session 8: Canada and U.S. Approaches to Health Care: How the Canadian and U.S. Political, Regulatory, and Legal Systems Impact Health Care, 31 CAN.-U.S. L. J. 287, 290 (2005).

83. Lemarquand, supra note 2.

84. Water Uses Reference, Final Report, available at http://www.ijc.org/php/publications/html/finalreport.html (last visited Apr. 6, 2009).

85. Email from Noah. D. Hall, infra note 87.

86. After 2000, the IJC's role was diminished by the Bush Administration's unilateralism, the relative decline in Canadian-United States relations and the strong United States commitment not to fetter state resource control with federal or international preemption. Oxford Analytica, supra note 22; see supra note 22 for a discussion of the Devil's Lake drainage conflict. The low point in the United States section came in July of 2007 when President George W. Bush fired the United States section co-chair, Dennis L. Schornack, a longtime, respected Michigan water manager. See, e.g., David Bauermaster, Firing by Bush Rejected By Boundary Official, SEATTLE TiMES (July 12, 2007), available at http://seattletimes.nw-source.com/html/localnews/2003785546_border $12 \mathrm{~m}$.html (last visited Apr. 6, 2009). Mr. Schornack's position also included the chairmanship of the Canada-United States Boundary Commission. Id. The Treaty requires a ten-foot open space on both sides of the border, and Mr. Schornack ordered the removal of all walls in the state of Washington that violated the ten-foot requirement. Id. After the property 
This said, the IJC concluded, after considerable internal debate, that a state-provincial effort was the best avenue to protect the Lakes. ${ }^{88}$ There was concern that if it did not, the United States federal government might instead preempt state efforts, as it had the full constitutional power to do, and the dedication of the lakes to regional uses might be subordinated to the possibility of national (arid) western use of the Lakes. ${ }^{89}$ Pursuant to the reference, the IJC prepared a report, which examined both the scientific and legal issues raised by the diversion threats. ${ }^{90}$ It marshaled available scientific research to underscore the need for a strong antidiversion regime.

\section{A. A Rationale for Leaving Twenty Percent of the World's Fresh Water in Place}

The Report blended a synthesis of the available science of the Lake's hydrology with the emerging, and much contested, international environmental law precautionary principle in order to counsel that the Great Lakes states and Canadian provinces were a strong anti-diversion regime. ${ }^{91}$ The foundation of this conclusion is the Report's mixed

owner complained to a powerful, local Republican official, sufficient pressure was generated to fire him for the sin of disrespecting private property rights. Id.

87. Dennis L. Schornack, who was appointed to the IJC by President George W. Bush and subsequently fired. See supra note 86. Mr. Schornack was Michigan Governor John Engler's primary policy advisor and one of the original architects of Annex 2001. See Dennis L. Schornack, Chairman, United States Section, available at http://rosenberg.ucanr.org/bios/Schornack\%20bio\%2006.pdf (last visited Apr. 6, 2009). He was replaced on the Commission by Dr. Sam Speck, who was the Ohio Department of Natural Resources Director under former Governor Taft. See Tom Henry, Ohian May Join Water Panel, President Bush Intends to Pick Ex-ODNR Director, THE BLADE (Dec. $21,2007)$, available at http://www.toledoblade.com/apps/pbcs.dll/article?AID=/20071221/NEWS06/712210352 (last visited Apr. 6, 2009). Dr. Speck was selected to chair the Council of Great Lakes Governors Water Management Working Group that oversaw the Compact's development and negotiation. Id. Professor Noah D.

Hall reports that

[m]ost people who saw the process up close would agree that Schornack was one of the most significant political leaders for Annex 2001, and Speck was definitely the main political leader on the compact through at least 2006 . So while the IJC as an institution did not oversee the compact process, its overlapping political leadership has.

E-mail from Noah D. Hall, Professor of Law, Wayne State University Law School (Dec. 14, 2008 14:29 CST) (on file with author).

88. Telephone Interview with Gerald Galloway, Secretary, United States Section, IJC 1998-2003, (Sept. 16, 2008).

89. Id.

90. Report, supra note 84.

91. Id. 
scientific economic classification of the lakes as a fragile, fully allocated "nonrenewable resource." This idea is a surprising and counterintuitive conclusion, given that the Great Lakes are currently used almost exclusively for non-consumptive uses. ${ }^{93}$

Nonrenewable resources are usually deep aquifers and mineral deposits rather than rain fed water bodies. ${ }^{94}$ Rivers and lakes are classic renewable resources and the conservation objectives and strategies are different. ${ }^{95}$ With non-renewable resources, the issue is the optimum rate of mining. ${ }^{96}$ With renewable water resources, the trick is balance consumptive uses with minimum flow demands constrained by estimates of average dependable supplies. ${ }^{97}$ Nonetheless, the Lakes have a fundamental non-renewable characteristic, a long renewal time, that makes them analogous to a deep aquifer. ${ }^{98}$ As the Report noted, less than one percent of the their total volume is renewed annually by precipitation and the levels remain relatively constant "with a normal fluctuation ranging from thirty to sixty $\mathrm{cm}$ (twelve-twenty-four inches) in a single year."

The line between a renewable and non-renewable resource is a matter of judgment, and the classification of the Lakes as fully allocated is a normative conclusion, which the Report was careful to underscore. ${ }^{100}$ An allocation of a river or lake can refer either to a situation where recognized property rights exceed the available dependable supply or to the dedication of a resource to a suite of uses to the exclusion of others. The latter, which is the case in the Great Lakes, is an economic or normative choice rather than a hydrologically constrained situation. As the IJC recognized, an existing resource use mix can always be changed. ${ }^{101}$ The IJC determined that the question is, what opportunity costs would be incurred by any change from the current allocation?

92. Id. at 5 .

93. ANNIN, supra note 11 , at 18 . (stating that only $1.5 \%$ of the renewable supply is consumed).

94. See, e.g., Ground Water Resources: The Sociotechnological Aspects of Nonrenewable Ground Water Resources, available at http://ngwa.confex.com/ngwa/renew08/techprogram/MEETING.HTM (last visited Apr. 6, 2009).

95. Id.

96. $I d$.

97. Id.

98. See Great Lakes Water Quality Agreement Review Environmental Community Discussion Paper (June 2006), available at http://www.canamglass.org/glwqa/files/AgrmntRev EnvirCmmtyDiscPaperfinal.pdf (last visited Feb. 8, 2009).

99. Report, supra note 84 , at 6.

100. Id.

101. Conversation with Galloway (on file with author). 
The observation that there would be opportunity costs just from any change in the status quo is not a compelling argument for the maintenance of the status quo. There were many suggestions that more consumptive uses should be allowed, because instead of costs there would be benefits from changing the status quo. ${ }^{102}$ Those familiar with the law of prior appropriation in the Western United States suggested that the states enter into a compact which would make a conventional allocation among the riparian states so they could then use the water as they wished. ${ }^{103}$ Some proposed a compact which would give each state a share. Others urged an allocation, but in a bow to the value of nonconsumptive uses recommended that it be constrained by a cap and trade program borrowed from the climate change debate. Thus, the Report had to take an additional step and provide a more convincing rationale for not incurring the opportunity costs of increased diversions and rejecting the lure of profitable interstate and international water markets.

The Report took this step by concluding that not only are the Lakes a non-renewable resource, but that they are a fragile one and thus change would involve risks. ${ }^{104}$ This is another non-intuitive conclusion to anyone who has seen the Lakes on a stormy, windy day or remembers the concern about shoreline erosion and flooding in the mid-1980. ${ }^{105}$ The basis of the fragility is the fact that lake levels fluctuate based on precipitation and evaporation cycles and even small seasonal fluctuations can have dramatic and costly consequences for the ecosystem and the maintenance of the primary commercial, non-consumptive use of the Lakes navigation. ${ }^{106}$ Lake shippers, owners of pleasure boat launching facilities, and shore land property owners have lived with short and long term fluctuating levels for years. ${ }^{107}$ For example, in the mid-1980s, the Lakes were high and the IJC studied ways to increase the flow to the Saint Lawrence River. ${ }^{108}$ However, since the mid 1980s, Lake levels have remained low; the current low period is perhaps the longest on

102. See Dick Lehnert, Great Lakes Water Compact Still Spurns Controversy, available at $\mathrm{http}: / / \mathrm{www}$.fruitgrowersnews.com/pages/arts.php?ns=791 (last visited Apr. 6, 2009).

103. See discussion, supra note 72.

104. Report, supra note 84 , at 5.

105. See A. Dan Tarlock, How Well Can International Water Allocation Regimes Adapt to Global Climate Change?, 15 J. LAND Use \& ENVTL. L, 423 (2000).

106. Id.

107. Id.

108. Id. 
record; although it is impossible to predict the incident and amplitude of future cycles. ${ }^{109}$

Natural level cycles have been altered over time by human intervention, such as diversions..$^{110}$ Chicago's diversion to reserve the flow of the Chicago River is the largest. ${ }^{11}$ The outflow from Lakes Superior and Ontario have been regulated by locks and dams, but only Lake Ontario's levels are significantly altered by the regulation. ${ }^{112}$ Sand and gravel dredging have also affected lake levels. ${ }^{113}$ However, compared to other large drainage systems, the Lakes are still a substantially unregulated system. ${ }^{114}$ Still, the evidence shows that diversions and other forms of regulation and diversion have not had a significant impact on seasonable variations levels makes the case for controlling speculative, future diversions weak.

The case strengthens if the prospect of global climate change is factored into the mix. The Report concluded that the Lakes are "highly sensitive to climatic variability." 115 It synthesized the various projected, but inconsistent, climate change scenarios to reach the bold conclusion that "[c]limate change suggests that some lowering of water levels is likely to occur ... . [and] the Commission believes that considerable caution should be exercised with respect to any factors potentially reducing water levels and outflows." 116

The precautionary principle is an evolving international environmental law norm. ${ }^{117}$ It can be stated in hard and soft versions, ${ }^{118}$

109. See Human Impacts on and Responses to Great Lakes Water Levels: Low Lake Levels, available at $\mathrm{http} / / /$ sitemaker.umich.edu/sec005group3/low_lake_levels (last visited Apr. 6, 2009).

110. Id.

111. See Brendan O'Shaughnessy, Indiana Towns Shut Out While Chicago Suburbs Flourish (Dec. 13, 2004), available at http://www.thetimesonline.com/articles/2004/12/13/news/top_news/balbc3c2c7fce2be86256f690003b52c.txt (last visited Apr. 7, 2009).

112. Frank H. Quinn, Secular Changes in Great Lakes Water Level Seasonal Cycles, 28 GREAT LAKES RES. 451, 455 (2002).

113. Id. at 452.

114. See Report, supra note 84.

115. Id. at 6 .

116. Id. at 24-25.

117. See UlRICh Beyerlin, DifFerent Types of NoRms IN INTERNational ENVIRONMENTAL LAW, THE OXFORD HANDBOOK OF INTERNATIONAL ENVIRONMENTAL LAW, 425 (Daniel Bodansky, Jutta Brunee \& Ellen Hay eds., 2007); Jonathan B. Weiner, Whose Precaution After All? A Comment on the Comparison and Evolution of Risk Regulatory Systems, 13 DUKE J. COMP. \& INT'L L. 207 (2003) (exploring the legal status of precaution).

118. The soft precautionary principle posits that a high degree of certainty about the adverse impacts of an activity is not a necessary prerequisite to limit or regulate it and is 
but the core idea is that the state has the power to limit activities that pose a risk of future harm when the available scientific evidence about the likelihood and magnitude remains uncertain and inconclusive. ${ }^{119}$ The United States has opposed the precautionary principle as a European import with the dangerous potential to undermine the more rigorous scientific foundations of United States environmental laws. ${ }^{120}$ However, the principle has been endorsed by the World Trade Organization ${ }^{121}$ and is increasingly applied.

The application of the principle to the Compact can be criticized because the probability and magnitude of the harm remain low, and the Compact chooses the crudest policy instrument, a total prohibition of the activity. ${ }^{122}$ However, the application can be defended because the opportunity costs of precaution are low. As long as the Lakes remain protected for non-consumptive uses, the exercise of precaution is a case of picking "the low hanging fruit." More broadly, the Compact is an important example of adoption of precaution in an international agreement.

one of the foundations of international environmental law. Gregory N. Mandel \& James Thuo Gathii, Cost-Benefit Analysis Versus the Precautionary Principle: Beyond Cass. Sunstein's Laws of Fear, 2006 U. ILL. L. REV. 1037, 1073 (2006). The hard version posits that an activity should not be allowed until there is conclusive evidence that it does not cause harm. The general principle was endorsed in the 1992 Rio Declaration on Environment and Development. See Rio Declaration on Environment and Development, princ. 15, U.N. Doc Al Conf. 151/5/Rev.1 (June 14, 1992), reprinted in 31 I.L.M. 874 (1992). Because crucial issues such as who bears the burden of proof and how feedback loops should operate remain unresolved, it remains much contested and has been criticized as incoherent and unfair. See, e.g., CASS SUNSTEIN, THE LAW OF FEAR: BEYOND THE PReCAUTIONARY PRINCIPLe (2005); Christopher D. Stone, Is There a Precautionary Principle?, 31 ENVTL. L. ReP. 10790, 10792 (2001); Frank B. Cross, Paradoxical Perils of the Precautionary Principle, 53 WASH. \& LEE L. REV. 851 (1996).

119. Mandel \& Gathii, supra note 118 , at 1073.

120. The best articulation of this position is found in Weiner, supra note 117; see also Jutta Brunnee, The United States and International Environmental Law: Living With an Elephant, 15 EUR. J. INT'L L. 617, 628-30 (2004) (discussing United States opposition in the broader context of the fear of general principles of customary law).

121. E.U. v. United States (WTO) is one of the fullest considerations of the principle. Panel Report, European Communities-Measures Affecting the Approval and Marketing of Biotech Products, WT/DS 291, 292, 293/R/Corr. 1 (Oct. 10, 2006). The Panel decision rejected the EU's formulation which would have allowed any doubt, regardless of the scientific foundation, to justify a regulatory action, in this case a ban on GMOs. The EU argued that certain GMOs present potential threats to human health and the environment. It submitted that the existence of a potential threat justified the assessment of risks on a case-by-case basis and special measures of protection based on the precautionary principle.

122. Sunstein suggests that the principle should be used when the magnitude of the harm is great and that prohibition should never be considered the only appropriate policy instrument. Sunstein, supra note 118, at 119-20 


\section{B. International Trade Law}

One of the persistent issues running through the Compact negotiations and debates was the fear that any regulatory regime which allowed any diversions would be found to be a violation of either NAFTA or GATT. ${ }^{123}$ The argument is both a series of hard, unresolved legal issues and political theater and continues to be raised. ${ }^{124}$ Since the late 1990s, environmental NGOs, especially Canadian nationalist Greens, have claimed that either the Dormant Commerce Clause of the United States Constitution or international trade law might preempt all state and provincial control of diversions. ${ }^{125}$ The basic argument was that any regime that allowed regulated diversions was therefore a "commodification" of the Lakes and could then be challenged as a disguised discriminatory trade practice. ${ }^{126}$

The argument makes three crucial, but doubtful, assumptions. First, it assumes that raw water is a "good" which triggers trade law. Second, it assumes that a nation-to-nation case would ever reach the WTO or NAFTA. Third, it assumes that there are no trade law defences to the anti-diversion policy. ${ }^{127}$

123. Tarlock, supra note 40 , at 1378.

124. Dellapenna, supra note 26 , at $788-90$.

125. See Scott S. Slater, State Water Resource Administration in the Free Trade Agreement Era: As Strong as Ever, 53 WAYNE L. REV. 649, 650-51 (2007) (presenting a collection of the most important sources for this argument).

126. See J. Owen Saunders, Trade Agreements and Environmental Sovereignty: Case Studies From Canada, 35 SANTA ClaRA L. Rev. 1171 (1995); Sanford E. Gaines, Fresh Water: Environment or Trade?, 28 CAN.-U.S. L. J. 157 (2002).

127. In addition to the lack of a threshold trigger, the Basin states have several possible trade law defenses. The WTO Agreement on the Application of Sanitary and Phytosanitary Measures (SPS Agreement) excepts science-based standards "only to the extent necessary to protect human, animal, plant life, or health ...." See David G. Victor, The Sanitary and Phytosanitary Agreement of the World Trade Organization: An Assessment After Five Years, 32 N.Y.U. J. INT'L L. \& PoL. 865 (2000); Sanford E. Gaines, Processes and Production Methods: How To Produce Sound Policy for Environmental PPM-based Trade Measures, 27 ColuM. J. ENVTL. L. 383 (2002). More to the point, Article XX provides an exception for a variety of domestic regulations including the protection of human health and the conservation of exhaustible resources. United StatesImport Prohibition of Certain Shrimp and Shrimp Products, APPELLATE BODY REPORT, WT/DS58/AB/R, paras. 119-120 (Nov. 6, 1998), reprinted in 38 I.L.M. 121 (1999) [hereinafter Shrimp/Turtle]. It also has a chapeau, which prohibits the application of exempted regulation in an arbitrary or discriminatory manner. Invoking both defenses would not be easy. The close cooperation between the two nations provides a basis to argue that this is not the kind of decision that requires WTO policing. WTO jurisprudence has evolved from an effort to isolate protectionist regulation to one which is willing to find that the failure of a nation to find alternative, cooperative means to achieve the regulatory objective constitutes trade discrimination. SUNGJOON CHO, FREE 
GATT and NAFTA prohibit national discrimination against the importation of goods similar to those produced (and protected) nationally. ${ }^{128}$ Thus, there is a threshold question: does the activity in question involve a produced good? GATT Article III allows environmental regulations which treat "foreign" goods differently from domestic ones to be challenged as illegal. A "victim" state can argue that such regulation is a disguised trade restriction, which confers an unjustified competitive advantage on domestic products at the expense of imported ones. National treatment is intended to curb blatant protectionism and performs the same function internationally as the Dormant Commerce Clause does domestically.

The threshold legal issue is whether water in its natural state is a product or good AND at what stage does the use of water become a good? Answers are only clear at either end of the cycle of water use. Raw water in its natural state in a lake or river has not entered the stream of commerce. ${ }^{129}$ It remains subject to the control of the sovereign country constrained only by any transboundary sharing duties. Further, there is no principle of trade law that forces a nation to engage in trade. Trade law only requires equal treatment of nationals and foreigners once the decision to trade is made. At the other end, once water is incorporated into a product, such as bottled water, it becomes subject to trade law. The gray areas involve diversions, storage and management decisions. ${ }^{130}$

Markets and Social Regulation: A Reform Agenda of the Global Trading SYSTEM 17- 90 (2003) (tracing this evolution). In addition, the IJC Report offers a partial justification for invoking the prevention of exhaustion of nonrenewable resources defense.

128. See sources cited, supra note 127.

129. In 1993, the three NAFTA governments issued a statement which asserts "[u]nless water, in any form, has entered into commerce and become a good or product, it is not covered by the provisions of any trade agreement including . . NAFTA." The Water Case Study, available at http://www.american.edu/ted/water.htm (last visited Apr. 6, 2009).

130. NAFTA Chapter 11, Section 1110 prohibits regulatory measures that are "tantamount to nationalization or expropriation" of "investments." The North American Free Trade Agreement: Chapter 11, available at http://dsp-psd.tpsgc.gc.ca/Collection$\mathrm{R} / \mathrm{LoPBdP} /$ inbrief/prb0254-e.htm (last visited Apr. 6, 2009). There is no NAFTA or WTO precedent on these issues. A Canadian-United States joint venture proposed to transport water from the Fraser River in British Columbia to California by tanker, but British Columbia imposed an export ban. In 1998, the United States company filed a Chapter 11 request for an arbitration, but its website, Sun Belt Water, Inc., contains no post-1998 information about the action. See Sun Belt Water-NAFTA-Bulk Water Transport, available at $\mathrm{http}: / / \mathrm{www}$. sunbeltwater.com/ (last visited Apr. 6, 2009). Given that a water right is usufructuary in all three countries, Chapter 11 should only be triggered after a country grants a right to export water and then claws it back. Prior to that time, the nation retains the sovereign right to decide what water rights, if any, it will 
In the run up to the Compact, the fate of the resource improvement standard illustrated the political force of this argument. The Lockheed Report recommended that the states apply a standard from section 404 of the Clean Water Act to the Lakes. ${ }^{131}$ Section 404 regulates the dredging and filling of wetlands. ${ }^{132}$ In 1989, the first Bush Administration adopted a "no net loss" standard. ${ }^{133}$ To accommodate this ambitious goal with land development, the U.S. Army Corps of Engineers can authorize the destruction of "natural" wetlands if compensating degraded ones are restored or artificial ones are developed. ${ }^{134}$

Under most drafts of the Compact, a diversion would have been allowed if there was a compensating resource improvement in the basin. ${ }^{135}$ Many environmental organizations were comfortable with the idea of allowing small diversions in return for significant wetland restoration or similar projects. ${ }^{136}$ However, in the end, Canadian objections appear to have forced its removal. ${ }^{137}$ Allowing a diversion to be traded off against a restored aquatic ecosystem was characterized as commodification.

There is no definitive legal precedent to resolution of this issue, but the Report played a significant role in dampening the legal and political force of the trade law objections to the Compact. It helped to strengthen the resolve of the eight Basin states and two Canadian provinces to proceed with a management regime and not to be spooked by the trade law invalidation horror scenarios floating through the basin. The Report identified the key legal issue as whether water in its natural state is a product or good for purposes of trade law and concluded that raw water that has not yet entered the stream of commerce is not a product or good. This conclusion was, of course, purely advisory, and the IJC has no special competence to pronounce on international trade law. But, subsequent analyses have confirmed the IJC's conclusion. A leading international environmental law lawyer, Edith Brown-Weiss, subsequently offered a powerful argument to support the conclusion:

recognize. See Paul Stanton Kibef, Grasp on Water: A Natural Resource That Eludes NAFTA's Notion of Investment, 34 ECOLOGY L. Q. 655 (2007).

131. ANNIN, supra note 11, at 202-10.

132. 33 U.S.C. § 1294-1281 (1977).

133. See, e.g., Bush Administration Proposes to Weaken vital Clean Water Act Permitting Program, EARTHJUSTICE, available at http://www.earthjustice.org/news/press/001/bush_administration_proposes_to_weaken_vital_clean_water_act_permitting_ program.html (last visited Apr. 6, 2009).

134. See id.

135. Id.

136. Id.

137. Id. 
it is essential to consider that water is different from other resources. It is a unique resource. . . . Thus, it would be prudent to adopt an approach of "anticipatory caution" to strike the appropriate balance between the need to conserve water resources and the need to ensure a level playing field in trade relationships. Anticipatory caution means that in the face of uncertainty about the future, a country should be able to exercise its full sovereignty to maintain its fresh water resources without having to convince the trade community of the legitimacy of its actions. ${ }^{138}$

\section{CONCLUSION: A MOMENT IN TIME}

This Article previously observed that the diversion reference was a moment in time. All the forces were in alignment for a successful outcome. The two section Secretaries saw eye-to-eye as to the vision and willingness to take political risks by taking a firm position on a contentious issue; the six commissioners were supportive and generally deferred to the staff. The two governments were in agreement, or at least the United States was indifferent so long as the Great Basin states supported it and there was no serious section opposition. Of course, the IJC Report was by no means responsible for the successful negotiation of the Compact. But, the negotiators were operating in uncharted waters and the threat of trade law challenges had to be taken seriously. The Report helped to provide a coherent scientific case for the first time and to "internationalize" the Compact by placing it in the context of emerging international law norms. These two contributions strengthened the legitimacy of a somewhat questionable enterprise. The result is a model of aquatic ecosystem protection, imperfect as it, which is being carefully studied around the world. And, the IJC's indirect role in this process is an example of how a treaty body can interpret its mandate broadly in light of the spirit of the treaty, and not just the inevitable narrower language of the instrument. ${ }^{139}$

The 100th anniversary of the Boundary Water Treaty celebrates another moment in time but one which is still very much with us. The first decade of the twentieth century was the birth of modernism, and in areas from culture to political institutions we are still living in that

138. Edith Brown Weiss, Water Transfers and International Trade LaW, IN FRESH WATER AND INTERNATIONAL ECONOMIC LAW 61, 83 (2005); Slater, supra note 125 reaches the same conclusion; but see Milos Barutciski, Trade Regulation of Fresh Water Exports: The Phantom Menace Revisited, 28 CAN.-U.S. L. J. 145,155-56 (2002).

139. Knox, supra note 22, at 1591. 
legacy. Canada and the United States experienced the decade differently, but the Treaty reflects a central experience in each country. In Canada, the Laurier government established Canada's independent authority to conduct international relations; ${ }^{140}$ the Treaty reflects Canada's new role as an equal, almost independent sovereign. Across the border, President Theodore Roosevelt (1900-1908), our first self-consciously modern president, ${ }^{141}$ led the scientific conservation movement. This movement was founded on using the best scientific and technical knowledge to manage natural resources to promote the public interest in their efficient use. Our notions of efficiency have changed, but the IJC's role in the Compact honors the conservationist spirit of the Treaty as well as the principle of bi-national equality. 